\title{
EVALUATION OF MATERNAL AND FOETAL OUTCOME IN TERM PREMATURE RUPTURE OF MEMBRANES MANAGED WITH EARLY INDUCTION
}

\author{
P. Nivedhana Arthi' ${ }^{1}$ B. Jalakandan ${ }^{2}$
}

${ }^{1}$ Assistant Professor, Department of Obstetrics and Gynaecology, Sri Lakshmi Narayana Institute of Medical Sciences, Puducherry. ${ }^{2}$ Assistant Professor, Department of Anaesthesiology and Critical Care, Sri Lakshmi Narayana Institute of Medical Sciences, Puducherry.

ABSTRACT

\section{BACKGROUND}

Premature Rupture of Membranes (PROM) occurs in 10\% of all pregnancies. The significance of PROM lies in the fact that it has obscure aetiology with difficulties in diagnosis and is associated with significant maternal and neonatal risks. There is still no universally accepted policy for the management of PROM at term.

\section{OBJECTIVES}

To identify the risk factors causing PROM and to study the labour outcomes and the maternal and perinatal morbidity and mortality in cases of PROM at term.

\section{METHODS}

This prospective descriptive study was conducted on seventy five patients with spontaneous rupture of membranes with gestational age $\geq 37$ weeks and managed with early induction. A detailed history and examination were carried out. All paramete rs of maternal and foetal wellbeing were recorded. A sterile speculum examination and amniotic fluid culture were done. Labour was induced with intravenous oxytocin. Data was collected using a structured questionnaire. Neonates with poor Apgar score were admitted in Neonatology Intensive Care Unit (NICU). Observations for signs of infection were continued in puerperium. Data regarding mode of delivery, foetal weight, foetal Apgar score, weight, and neonatal outcome were recorded.

\section{RESULTS}

PROM occurs more frequently in unbooked, nulliparous women of low socioeconomic class. Incidence of LSCS (44\%) and instrumental delivery (28\%) were higher. E. coli (42.5\%) was the most common pathogen isolated from vagina followed by commensals $(17.5 \%)$. Puerperal pyrexia $(10.7 \%)$ was a major cause for maternal morbidity followed by wound infection $(2.7 \%)$ and chorioamnionitis (1.3\%). $27.6 \%$ of the neonates required NICU observation for mild respiratory distress. $5.3 \%$ of neonates were admitted for perinatal asphyxia and $2.6 \%$ of neonates were admitted for neonatal sepsis. No perinatal deaths were there. Infections have increased with increasing period of latency.

\section{CONCLUSION}

Overall incidence of maternal and neonatal infectious complications were very less in our study. The early induction of patie nts in our study by reducing the duration of latency had contributed for the reduction in the incidence of infectious complications.

\section{KEYWORDS}

Premature Rupture of Membranes, Chorioamnionitis, Perinatal Asphyxia, Neonatal Sepsis, Bishop Score.

HOW TO CITE THIS ARTICLE: Arthi PN, Jalakandan B. Evaluation of maternal and foetal outcome in term premature rupture of membranes managed with early induction. J. Evolution Med. Dent. Sci. 2016;5(59):4092-4099, DOI: 10.14260/jemds/2016/936

\section{INTRODUCTION}

Premature Rupture of Membranes (PROM) is defined as rupture of membranes with a latent period before the onset of spontaneous uterine activity and can occur at any gestational age. The significance of PROM lies in the fact that it has obscure aetiology with difficulties in diagnosis and is associated with significant maternal and neonatal risks. PROM occurs in $10 \%$ of all pregnancies with majority of cases (60-70\%) occurring before 37 completed weeks of gestation. $(1,2)$

Financial or Other, Competing Interest: None.

Submission 22-05-2016, Peer Review 05-07-2016,

Acceptance 11-07-2016, Published 23-07-2016.

Corresponding Author:

Dr. P.Nivedhana Arthi,

Department of Obstetrics and Gynaecology,

Sri Lakshmi Narayana

Institute of Medical Sciences,

Puducherry-605502.

E-mail: sujanjala@gmail.com

DOI: $10.14260 /$ jemds $/ 2016 / 936$
Unfortunately, $5 \%$ to $10 \%$ of women will not enter labour within 72 hours and $2 \%$ to $5 \%$ remain undelivered 7 days after PROM at term. Infections of lower genital tract and amniotic cavity are most common aetiologies of PROM.(3) PROM is associated with severe maternal and neonatal complications. $(4,5)$

There is no golden standard for diagnosing rupture of the membranes. The management strategies of PROM at term are diverse and controversial. Despite the extensive research and studies done in this field, there is still no universally accepted policy for the management of PROM at term and management varies between immediate induction and awaiting a certain period of time.(6)

With this magnitude and seriousness of the condition, the main objective for the obstetrician and for the woman with suspected PROM is a correct diagnosis and management that gives a high rate of successful vaginal deliveries without a rise in neonatal and maternal infections.

Hence, this study was conducted to identify the risk factors and to study the labour outcomes and the maternal 
and perinatal morbidity and mortality in patients with PROM at term managed with early induction.

\section{AIMS AND OBJECTIVES}

- To identify the risk factors causing PROM.

- To study the labour outcomes and the maternal and perinatal morbidity and mortality in cases of PROM at term.

\section{MATERIALS AND METHODS}

This prospective, descriptive study was conducted on seventy five consecutive patients of spontaneous rupture of membranes with gestational age 37 to 40 weeks. Informed consent was obtained from all these patients.

\section{Inclusion Criteria}

- Gestation age group 37 to 40 weeks.

- Clinical confirmation of PROM by speculum examination.

\section{Exclusion Criteria}

- Antepartum haemorrhage.

- Preterm PROM.

- Anomalous baby.

- Intrauterine Death.

\section{Procedure of Study}

Patients with history suggestive of PROM were admitted to the labour room. A detailed history including age, menstrual history, high risk pregnancy, duration of pregnancy, gestational order, previous rupture of membranes, urinary tract infection within pregnancy, antibiotic intake, presentation of chorioamnionitis symptoms were all recorded and obstetric history with emphasis on exact time of membrane rupture, duration, and amount of leaking were recorded.

Thorough general and systemic examination including pulse, blood pressure, and temperature were recorded. In obstetric examination, uterine height, presentation, lie of foetus, and amount of liquor were noted. All parameters of maternal and foetal wellbeing were recorded.

A sterile speculum examination was conducted and presence of liquor amnii was noted and when no amniotic fluid was seen, the patient was asked to cough to see the drainage of amniotic fluid. In case of doubt, fluid from vagina was collected on slide and examined for $\mathrm{pH}$ and microscopically examined for ferning. Amniotic fluid culture (By cervical swab) were sent.

Obstetrical ultrasound was carried to confirm gestational age to assess the amount of liquor and to rule out congenital anomalies.

The Clinical Diagnosis of Chorioamnionitis was made in Presence of two or more of the following Criteria.(7)

- Maternal fever greater than $38^{\circ} \mathrm{C}$.

- Maternal tachycardia ( 90 beats per minute or more).

- Leucocytosis (WBCs $\geq 20,000 / \mathrm{mm}^{3}$ ).

- Foetal tachycardia ( $>160$ beats per minute).

- Uterine tenderness.

- Foul-smelling amniotic fluid.

Pelvic examination was done to note the membranes, presenting part, and its station. Bishop score was assessed and cord prolapse was excluded. Patients were induced with intravenous oxytocin diluted in Ringers Lactate. Its dose was adjusted according to uterine response intermittently. All cases were given prophylactic antibiotic at the time of admission. Data was collected using a structured questionnaire.

Maternal pulse, BP, temperature, uterine contractions, abdominal palpation to detect uterine tenderness, colour, and smell of liquor were recorded $4^{\text {th }}$ hourly. Continuous electronic monitoring of maternal pulse, foetal heart rate, and partogram were done.

Success of induction was declared when effective uterine contractions were started along with improvement in Bishop score. Labour was then augmented if required. If there was failure to induce labour in 24 hours or evidence of maternal or foetal compromise, caesarean section was done. Antibiotics were given to babies after delivery with evidence of chorioamnionitis. Neonates with poor Apgar score were admitted in Neonatology Intensive Care Unit (NICU). Total hospital stay was noted. Observations for signs of infection were continued in puerperium.

Data regarding mode of delivery, foetal weight, foetal Apgar score, weight, and neonatal outcome were recorded on the proforma.

Maternal outcome was measured on the basis of presence of fever, mode of delivery. Foetal outcome was measured on the basis of presence of infection (Sepsis), Apgar score, and neonatal morbidity.

\section{STATISTICAL ANALYSIS}

At the end of the study, all gathered data in questionnaire was tabulated and interpreted. All categorical data was presented as number and percentage. Data was tested for significance with the chi-square test and Fisher exact tests. Statistical analysis was carried out using SPSS 15.0 version. P value $<0.05$ was considered statistically significant.

\section{OBSERVATION AND RESULTS}

The majority of patients were in the age group of 21-25 years (Table 1, Fig.1) and most were unbooked (Table 2, Fig.2) and nulliparous (Table 3, Fig.3). The difference was statistically very significant $(\mathrm{p}<0.001)$.

The major risk factors were low socioeconomic class $(62.7 \%)$ and primiparity (57.3\%). More than $65.3 \%$ of the patients had more than one risk factors (Table 4, Fig.4). All the patients had an alkaline vaginal pH (Table 6, Fig.6).

The incidence of LSCS (44\%) and instrumental delivery (28\%) were higher (Table 7, Fig.7) with non-reassuring foetal heart rate $(54.5 \%)$ as the most common indication for LSCS followed by cephalopelvic disproportion (27.3\%) (Table 8 , Fig.8) and it was statistically very significant $(\mathrm{p}<0.001)$.

At the time of admission, majority of patients had an unfavourable cervix with Bishop score $<6$ (Table 5, Fig.5) and correspondingly the higher incidence of LSCS (54.9\%) and instrumental delivery (27.5\%) (Table 9, Fig.9).

E. coli $(42.5 \%)$ was the most common pathogen isolated followed by commensals $(17.5 \%)$. No growth was seen in $32.5 \%$ of cases. (Table 10, Fig.10).

The table 11 shows significant incidence of complications $(14.7 \%)$ in women with PROM, with puerperal pyrexia $(10.7 \%)$ as a major cause for maternal morbidity followed by 
wound infection (2.7\%) (Fig.11). The table 12 shows significant number of neonates $(27.6 \%)$ required NICU observation for mild respiratory distress and 5.3\% of neonates were admitted in NICU for perinatal asphyxia and $2.6 \%$ of neonates were admitted for neonatal sepsis. There were no perinatal deaths (Fig.12).

Majority $(80 \%)$ of the patients had their latency period $<12$ hours, $14.7 \%$ of patients had between $12-24$ hours and $5.3 \%$ of patients had more than 24 hours. Neonatal sepsis was not seen in neonates delivered within 24 hours of latency, but seen in $50 \%$ of neonates when latency exceeds 24 hours (Table 13, Fig.13).

\section{DISCUSSION}

Approximately $8-10 \%$ of term pregnancies will experience spontaneous ROM prior to the onset of uterine activity.(1) Infections of lower genital tract and amniotic cavity are most common aetiologies of PROM.(3) There is good evidence to support the association between PROM and infection with Chlamydia trachomatis.(8) and Neisseria gonorrhoea.(9) Two or more induced abortions.(10) antepartum vaginal bleeding.(11) were also a risk factor for PROM. Other factors include lower socioeconomic status, cigarette smoking, prior cervical conization, prior preterm delivery, uterine distention (e.g., twins, hydramnios), cervical cerclage, and amniocentesis. Each of these may be associated with PROM through membrane stretch or degradation, local inflammation, or a weakening of maternal resistance to ascending bacterial colonization. In many cases, the ultimate cause of PROM was unknown.

The mechanisms by which rupture takes place must be related to a weakness in the chorioamniotic membrane. BouResli et al had found that the membranes are thinner near the rupture site and the connective tissue layer contains a decreased number of poorly-organised collagen fibrils.(12) With biochemical techniques, it has been shown that there is a decline in the collagen content of the prematurely ruptured amnion.(13) Polzin et al had concluded that amniorrhexis occurs as a result of proteolytic enzyme-mediated weakening of the foetal membranes in the region of the cervix or the lower uterine segment.(14)

Risks of PROM include risk of subclinical chorioamnionitis, increased likelihood of operative delivery, increased incidence of marginal cord insertion, and battle door placenta, which itself is associated with retained placenta and both primary and secondary postpartum haemorrhage. Risk of abruptio placentae is $4-7 \%$, postpartum endomyometritis is $10 \%$, and there is also risk of maternal pyelonephritis. ${ }^{(4)}$ Reported incidence of neonatal sepsis is $2-4 \%$. Foetal hypoxia may occur due to cord prolapse, cord compression, and abruptio placentae. Due to reduced volume of amniotic fluid, mechanical difficulties may occur in delivery resulting in neonatal morbidity. Additionally, prematurity, sepsis and respiratory distress syndrome (RDS) can also occur.(5)

The Traditional Minimally Invasive 'Gold Standard' for the Clinical Diagnosis of ROM relies on the ability of the Clinician to Document Two of Three Clinical Signs

- Visual 'pooling' of clear fluid in the posterior fornix of the vagina or leakage of fluid from the cervical os at the time of first sterile speculum examination;
- An alkaline pH of the cervicovaginal discharge ('Nitrazine test'); and/or;

- ' Ferning' of the cervicovaginal discharge on drying.

The management strategies of PROM at term were diverse and controversial. Despite the extensive research and studies done in this field, there was still no universally accepted policy for the management of PROM at term and management varies between immediate induction and awaiting a certain period of time.(6)

Currently available evidence supports the induction of labour when PROM occurs at term to decrease the risk for maternal infections. $(2,6)$ Expectant management carries high risk of maternal and neonatal infection as the latent period lengthens along with increased risk of umbilical cord compression and abruptio placentae. However, the main aim should be to deliver the baby before the signs of chorioamnionitis appear. Expectant management, also prolonged hospital stay maybe associated with worsening of perinatal outcome.(15)

The present study was undertaken to identify the risk factors and to study the labour outcomes and the maternal and perinatal morbidity and mortality in cases of PROM managed with early induction.

In our study, majority of the patients $(54.7 \%)$ were in the age group of $21-25$ years followed by $25.3 \%$ of patients in the age group of 26-30 years. Similar distribution was also seen in the study by Amjad et al(3) Most of the cases (74.7\%) were unbooked similar to the study by Jolly et al(16) Most of the cases were booked elsewhere and ours being a referral centre, these cases were referred after membrane rupture and $62.7 \%$ of our patients belong to low socioeconomic class and their level of awareness and compliance were very low and that could partly explain the reason for such a high incidence of the unbooked cases in our study. Similarly, the low incidence of PROM in the booked cases in our study could be explained by good and regular antenatal checkups, identification of high risk cases, prediction of PROM in those cases, and appropriate management including early induction.

Our study had revealed that PROM occurs more frequently in nulliparous women (57.3\%). Similarly, Fatehmeh et al(17) and Hassan et al(18) in their study had reported the incidence of PROM in nulliparous women as $59.7 \%$ and $50 \%$, respectively. The major risk factors were low socioeconomic class $(62.7 \%)$ and primiparity (57.3\%). Other risk factors were genitourinary infection in current pregnancy (16\%), history of abortions (14.7\%), recent coitus (10.7\%), previous history of PROM (8\%), malpresentations (6.7\%), and multiple gestation (1.3\%).

Ladfors et al had suggested that differences in risk factors between the studies could be attributed to differences in the populations in which they were studied.(19) Low socioeconomic class as a risk factor for PROM had been reported in many studies. $(18,20,21)$ The reason for a high incidence in our study could be explained by the fact that our hospital services were meant for managing poor patients.

Ladfors et al had suggested primiparity as one of the major risk factor for PROM.(19) Fatehmeh et al(17) and Hassan et al(18) had reported the incidence as $59.7 \%$ and $50 \%$ respectively. Genitourinary infection in current pregnancy as another risk factor had been reported in many studies. $(3,20,22)$ 
Linn et al(10)and Harger et al(23) had found an association between a previous elective abortion or a previous dilatation and curettage and PROM. Naeye et al(24) and Mills et al(25) had observed sexual intercourse as a major risk factor for PROM. Ladfors et al(19) Romero et al(22) and Harger et al(23) had concluded PROM in a previous pregnancy as one of the major risk factor. More than $65.3 \%$ of the patients had more than one risk factors and this finding was supported by Hassan et al(18) and Ladfors et al(19)

All the patients had an alkaline vaginal pH. Jolly et al(16) and Erdemoglu et al(26) had reported that the sensitivity and specificity of this test in diagnosing ROM ranges from 90 to $97 \%$ and 16 to $70 \%$, respectively.

Incidence of LSCS (44\%) and instrumental delivery (28\%) were higher when compared to normal vaginal delivery. Frequency of operative deliveries had been reported as $48.4 \%$ by Grant et al(27) as $39.2 \%$ by Hannah et al(2) and $32 \%$ by Hassan et al(18) Non-reassuring foetal heart rate (54.5\%) was the most common indication for LSCS followed by cephalopelvic disproportion (27.3\%), as reported by Hannah et $\mathrm{al}^{(2)}$ and Fatehmeh et al(17)

At the time of admission, majority of patients (68\%) had an unfavourable cervix with Bishop score less than 6 as observed by Jolly et al(16) and Rhydstrom et al(28) There were higher incidence of LSCS (54.9\%) and instrumental delivery $(27.5 \%)$ in patients with poor Bishop score as concluded by Ladfors et al(19) and Rhydstrom et al(28)in their studies.

E. coli $(42.5 \%)$ was the most common pathogen followed by commensals $(17.5 \%)$. Candida was isolated in $5 \%$ of cases and coagulase-negative Staphylococci in $2.5 \%$ of cases. Imseis et $\mathrm{al}^{(29)}$ had found a heavier growth in $84 \%$ of the patients and majority of growth were E. coli.

In our study, $14.7 \%$ of patients had complications with puerperal pyrexia $(10.7 \%)$ as a major cause for maternal morbidity followed by wound infection (2.7\%) and chorioamnionitis $(1.3 \%)$. Shehla et al(21) had reported the incidence of puerperal pyrexia as $44.7 \%$ and Jolly et al(16) as $7.58 \%$. Incidence of wound infection had been reported as $6 \%$ by Chaim et al ${ }^{(30)}$ and $2 \%$ by Andrews et al (31) Incidence of Chorioamnionitis had been reported as $4 \%$ by Hannah et al(2) and $1.6 \%$ by Ottervanger et al.(32)

In our study, significant number of neonates $(27.6 \%)$ required NICU observation for mild respiratory distress and $5.3 \%$ of neonates were admitted in NICU for perinatal asphyxia and $2.6 \%$ of neonates were admitted for neonatal sepsis. There were no perinatal deaths. Hannah et al(2) Seaward et $\mathrm{al}^{(4)}$ and Ladfors et al(19) had found the rate of neonatal infection as $2.0-3.0 \%$, which is similar to our figures. Hassan et al(18) had reported perinatal asphyxia in $8.6 \%$ of babies following PROM.

In our study, majority $(80 \%)$ of the patients had their latency period $<12$ hours, $14.7 \%$ of patients had between 12 24 hours, and $5.3 \%$ of patients had more than 24 hours. It was clearly evident that infections have increased with increasing period of latency with puerperal pyrexia occurring in $45.5 \%$ of patients with latency period between $12-24$ hours and $25 \%$ of patients with latency period more than 24 hours. Neonatal sepsis was not seen in neonates delivered within 24 hours of latency, but seen in $50 \%$ of neonates when latency exceeds 24 hours. Ladfors et al(33) and Yancey et al(34) in a stepwise logistic regression analysis had found a significant association between clinical sepsis and latency period.

The early induction of patients in our study by reducing the duration of latency had contributed for the reduction in the incidence of infectious complications. Maternal infectious morbidity as measured by the incidence of chorioamnionitis was lowest in deliveries managed by immediate oxytocin induction. The delayed induction was associated with an increase of neonatal infectious morbidity.(35)

\begin{tabular}{|c|c|c|c|c|}
\hline Age & No. of Cases & $\mathbf{\%}$ & 't' value & Significance \\
\hline$\leq 20$ yrs. & 13 & 17.3 & & \\
\cline { 1 - 3 } $21-25$ & 41 & 54.7 & & \multirow{2}{*}{0.000} \\
\hline $26-30$ & 19 & 25.3 & 25.559 & \\
\hline $31-35$ & 2 & 2.7 & & \\
\hline$\geq 35$ & 0 & 0 & & \\
\hline \multicolumn{5}{|c|}{ Table 1: Age-Wise Distribution } \\
\hline
\end{tabular}

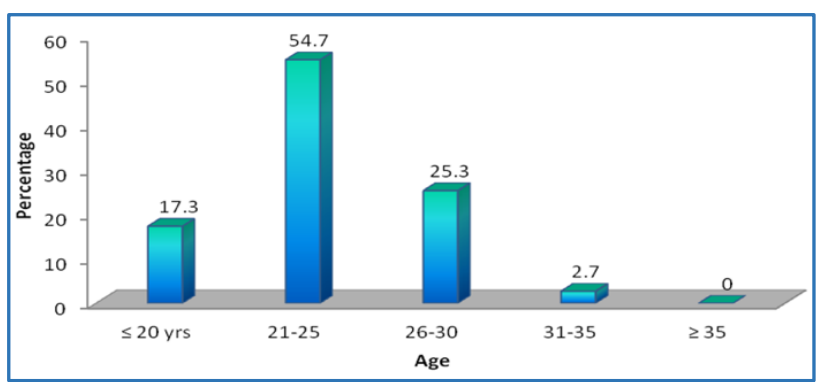

Fig. 1: Age-Wise Distribution

\begin{tabular}{|c|c|c|c|c|}
\hline ANC & $\begin{array}{c}\text { No. of } \\
\text { Cases }\end{array}$ & $\mathbf{\%}$ & 't' value & Significance \\
\hline Booked & 19 & 25.3 & \multirow{2}{*}{34.547} & 0.000 \\
\hline Unbooked & 56 & 74.7 & & \\
\hline \multicolumn{4}{|c|}{ Table 2: Relation to Antenatal Care (ANC) } \\
\hline
\end{tabular}

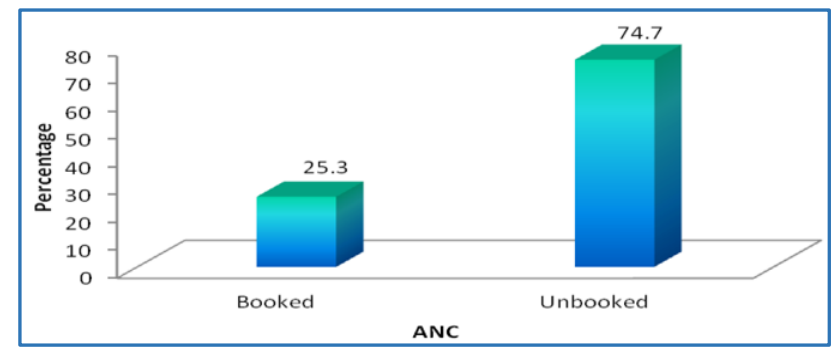

Fig. 2: Relation to Antenatal Care (ANC)

\begin{tabular}{|c|c|c|c|c|}
\hline Gravida & $\begin{array}{c}\text { No. of } \\
\text { cases }\end{array}$ & $\begin{array}{c}\text { ' } \mathbf{~} \mathbf{t} \text { ' value } \\
\text { Significance }\end{array}$ \\
\hline Nulliparous & 43 & 57.3 & \multirow{2}{*}{24.814} & 0.000 \\
\hline Multiparous & 32 & 42.7 & \\
\hline \multicolumn{4}{|c|}{ Table 3: Parity-Wise Distribution of Cases } \\
\hline
\end{tabular}

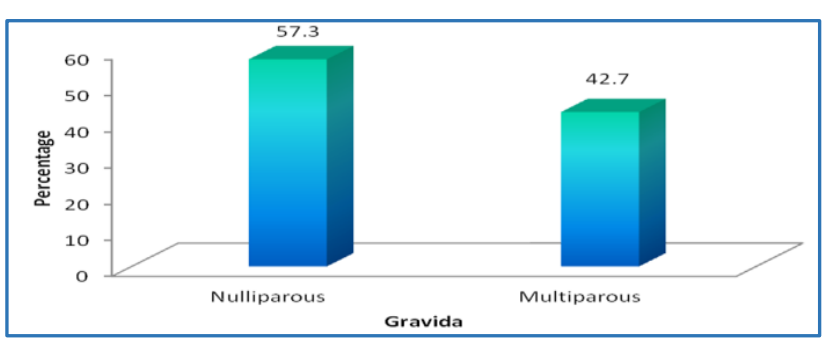

Fig. 3: Parity-Wise Distribution of Cases 


\begin{tabular}{|c|c|c|c|c|}
\hline $\begin{array}{c}\text { Risk } \\
\text { Factors } \\
\end{array}$ & $\begin{array}{l}\text { No. of } \\
\text { Cases }\end{array}$ & $\%$ & $\begin{array}{c}t ' \\
\text { value }\end{array}$ & $\begin{array}{r}\text { Signifi- } \\
\text { cance }\end{array}$ \\
\hline $\begin{array}{c}\text { Low socioeconomic } \\
\text { class }\end{array}$ & 47 & 62.7 & \multirow{10}{*}{12.447} & \multirow{10}{*}{0.000} \\
\hline Primigravida & 43 & 57.3 & & \\
\hline Breech & 5 & 6.7 & & \\
\hline $\mathrm{H} / \mathrm{O}$ recent coitus & 8 & 10.7 & & \\
\hline Previous $\mathrm{H} / \mathrm{O}$ prom & 6 & 8 & & \\
\hline Abortions & 11 & 14.7 & & \\
\hline $\begin{array}{l}\text { Genitourinary } \\
\text { infections }\end{array}$ & 12 & 16 & & \\
\hline Polyhydramnios & 0 & 0 & & \\
\hline Twins & 1 & 1.3 & & \\
\hline Unknown & 7 & 9.3 & & \\
\hline \multicolumn{5}{|c|}{ Table 4: Risk Factors for PROM } \\
\hline
\end{tabular}

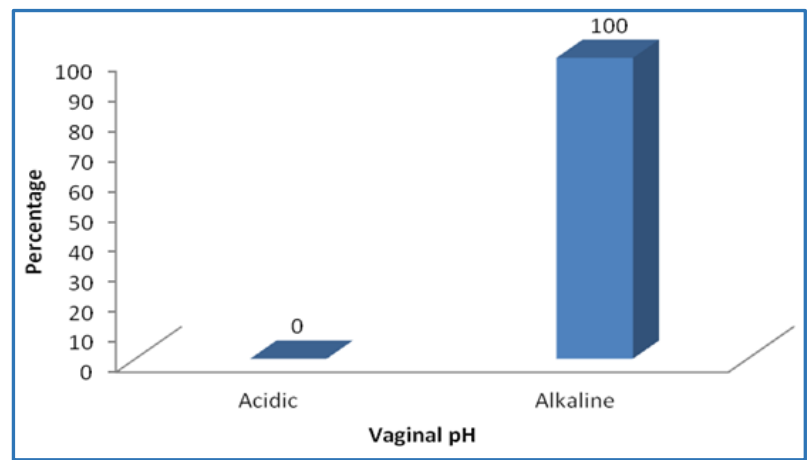

Fig. 6: Vaginal pH

\begin{tabular}{|c|c|c|c|c|}
\hline $\begin{array}{l}\text { Mode of } \\
\text { Delivery } \\
\end{array}$ & $\begin{array}{l}\text { No. of } \\
\text { Cases }\end{array}$ & $\%$ & 't' value & $\begin{array}{c}\text { Significan } \\
\text { ce }\end{array}$ \\
\hline $\begin{array}{c}\text { Full-term } \\
\text { vaginal } \\
\text { delivery } \\
\text { with RMLE } \\
\text { (FTVD } \\
\text { with } \\
\text { RMLE) } \\
\end{array}$ & 18 & 24.0 & \multirow{5}{*}{17.821} & \multirow{5}{*}{0.000} \\
\hline $\begin{array}{c}\text { Assisted } \\
\text { breech } \\
\text { extraction }\end{array}$ & 3 & 4.0 & & \\
\hline $\begin{array}{c}\text { Outlet } \\
\text { forceps } \\
\text { delivery } \\
\text { with RMLE }\end{array}$ & 21 & 28.0 & & \\
\hline $\begin{array}{l}\text { Vacuum } \\
\text { Delivery }\end{array}$ & 0 & 0.0 & & \\
\hline LSCS & 33 & 44.0 & & \\
\hline
\end{tabular}

\begin{tabular}{|c|c|c|c|c|}
\hline $\begin{array}{c}\text { Bishop } \\
\text { Score }\end{array}$ & $\begin{array}{c}\text { No. of } \\
\text { cases }\end{array}$ & $\mathbf{\%}$ & 't' value & Significance \\
\hline$<6$ & 51 & 68 & \multirow{2}{*}{24.342} & 0.000 \\
\hline$>6$ & 24 & 32 & \\
\hline \multicolumn{4}{|c|}{ Table 5: Bishop Score at Admission } \\
\hline
\end{tabular}

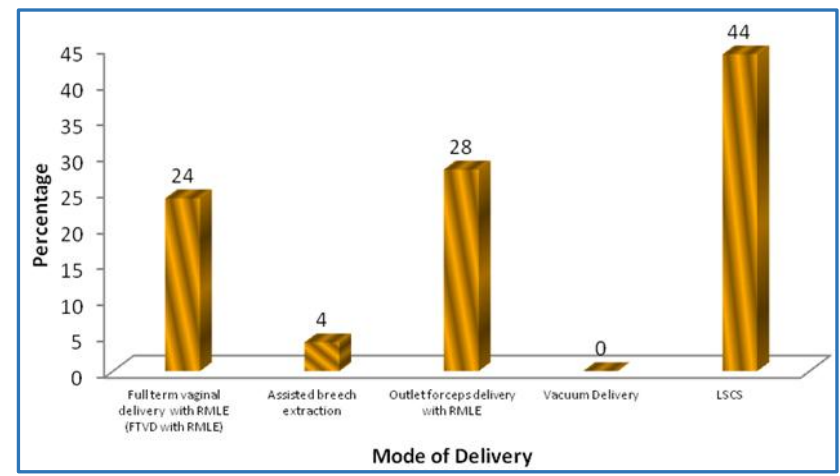

Fig. 7: Mode of Delivery

Total No .of cases 33

\begin{tabular}{|c|c|c|c|c|}
\hline Indications & $\begin{array}{c}\text { No. of } \\
\text { cases }\end{array}$ & $\%$ & $\begin{array}{c}\text { 't' } \\
\text { value }\end{array}$ & $\begin{array}{c}\text { Significan } \\
\text { ce }\end{array}$ \\
\hline $\begin{array}{c}\text { Non- } \\
\text { reassuring } \\
\text { foetal heart } \\
\text { rate }\end{array}$ & 18 & 54.5 & & \\
\cline { 1 - 3 } $\begin{array}{c}\text { Previous } \\
\text { LSCS with } \\
\text { PROM }\end{array}$ & 1 & 3.0 & \multirow{2}{*}{7.837} & \multirow{2}{*}{0.000} \\
\cline { 1 - 2 } $\begin{array}{c}\text { Failed } \\
\text { induction }\end{array}$ & 2 & 6.1 & & \\
\hline Breech & 2 & 6.1 & \\
\hline CPD & 9 & 27.3 & \\
\hline Twin & 1 & 3.0 & \\
\hline \multicolumn{3}{|c|}{ Table 8: Indications for LSCS. } \\
\hline
\end{tabular}




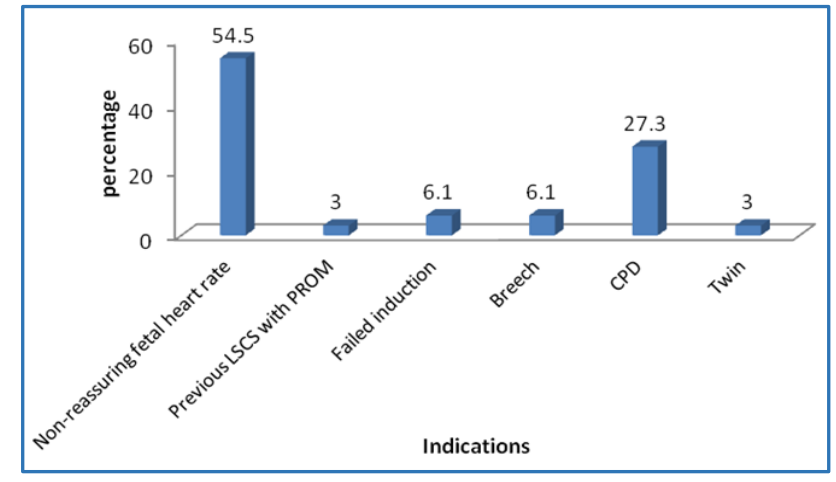

Fig. 8: Indications for LSCS.

\begin{tabular}{|c|c|c|c|c|}
\hline \multirow{3}{*}{$\begin{array}{l}\text { Mode of } \\
\text { Delivery }\end{array}$} & \multicolumn{2}{|c|}{ Bishop score } & \multirow{3}{*}{$\begin{array}{l}\text { Chi- } \\
\text { square } \\
\text { value }\end{array}$} & \multirow{3}{*}{$\begin{array}{c}\text { Significa } \\
\text { nce }\end{array}$} \\
\hline & $<6$ & $\geq 6$ & & \\
\hline & $\begin{array}{c}51 \\
(68 \%)\end{array}$ & $\begin{array}{c}24 \\
(32 \%)\end{array}$ & & \\
\hline $\begin{array}{l}\text { FTVD with } \\
\text { RMLE }\end{array}$ & $\begin{array}{c}8 \\
(15.7 \%)\end{array}$ & $\begin{array}{c}10(41.7 \\
\%)\end{array}$ & \multirow{5}{*}{10.569} & \multirow{5}{*}{0.015} \\
\hline $\begin{array}{l}\text { Assisted } \\
\text { breech } \\
\text { extraction }\end{array}$ & $\begin{array}{c}1 \\
(2 \%)\end{array}$ & $2(8.3 \%)$ & & \\
\hline $\begin{array}{c}\text { Outlet } \\
\text { forceps } \\
\text { delivery } \\
\text { with RMLE }\end{array}$ & $\begin{array}{c}14 \\
(27.5 \%)\end{array}$ & $\begin{array}{c}7 \\
(29.2 \%)\end{array}$ & & \\
\hline $\begin{array}{l}\text { Vacuum } \\
\text { Delivery }\end{array}$ & $\begin{array}{c}0 \\
(0 \%)\end{array}$ & $\begin{array}{c}0 \\
(0 \%)\end{array}$ & & \\
\hline LSCS & $\begin{array}{c}28 \\
(54.9 \%)\end{array}$ & $\begin{array}{c}5 \\
(20.8 \%)\end{array}$ & & \\
\hline Table & $\begin{array}{r}\text { Relation o } \\
\text { to } M\end{array}$ & $\begin{array}{l}\text { Bishop Scc } \\
\text { e of Deliv }\end{array}$ & $\begin{array}{l}\text { e on } A d \\
y\end{array}$ & sion \\
\hline
\end{tabular}

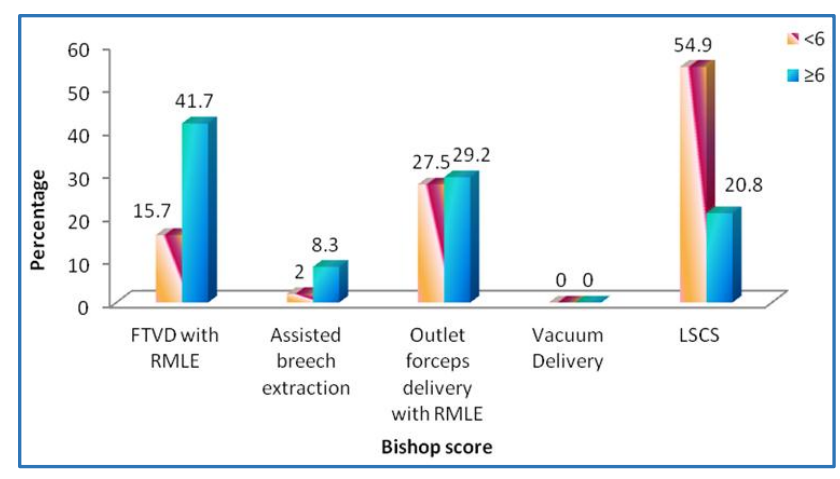

Fig. 9: Relation of Bishop Score on Admission to Mode of Delivery

Total No .of cases 40

\begin{tabular}{|c|c|c|c|c|}
\hline Organism & $\begin{array}{l}\text { No. of } \\
\text { Cases }\end{array}$ & $\%$ & $\begin{array}{c}t ' \\
\text { value }\end{array}$ & $\begin{array}{c}\text { Significa } \\
\text { nce }\end{array}$ \\
\hline E. coli & 17 & 42.5 & \multirow{5}{*}{9.459} & \multirow{5}{*}{0.000} \\
\hline Commensals & 7 & 17.5 & & \\
\hline $\begin{array}{l}\text { Coagulase } \\
\text { negative } \\
\text { staphylococci }\end{array}$ & 1 & 2.5 & & \\
\hline Candida & 2 & 5.0 & & \\
\hline No growth & 13 & 32.5 & & \\
\hline \multicolumn{5}{|c|}{ Table 10: Amniotic Fluid Culture from Suspected Cases } \\
\hline
\end{tabular}

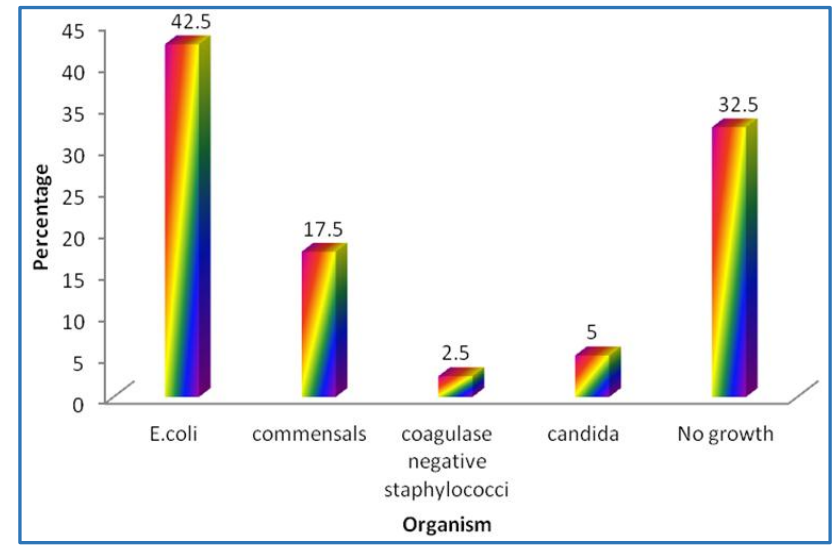

Fig. 10: Amniotic Fluid Culture from Suspected Cases

\begin{tabular}{|c|c|c|c|c|}
\hline Complications & $\begin{array}{l}\text { No. of } \\
\text { cases }\end{array}$ & $\begin{array}{c}\text { Percent } \\
\text { age }\end{array}$ & $\begin{array}{c}\text { 't' } \\
\text { value }\end{array}$ & $\begin{array}{c}\text { Significa } \\
\text { nce }\end{array}$ \\
\hline $\begin{array}{c}\text { Puerperal } \\
\text { pyrexia }\end{array}$ & 8 & 10.7 & \multirow{4}{*}{$\begin{array}{c}32.87 \\
4\end{array}$} & \multirow{4}{*}{0.000} \\
\hline $\begin{array}{l}\text { Chorioamnionit } \\
\text { is }\end{array}$ & 1 & 1.3 & & \\
\hline $\begin{array}{c}\text { Wound } \\
\text { infection }\end{array}$ & 2 & 2.7 & & \\
\hline $\begin{array}{c}\text { No } \\
\text { complications }\end{array}$ & 64 & 85.3 & & \\
\hline
\end{tabular}

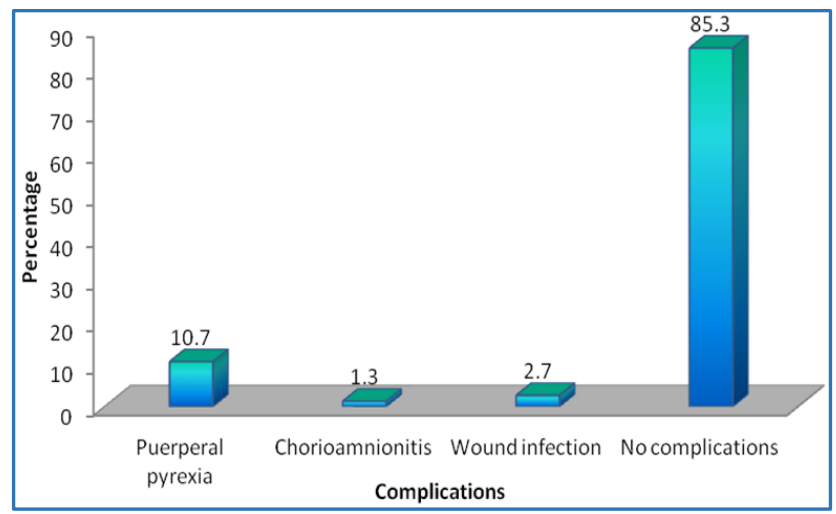

Fig. 11: Maternal Morbidity

Total no of cases 76

\begin{tabular}{|c|c|c|c|c|}
\hline Complications & $\begin{array}{l}\text { No. of } \\
\text { cases }\end{array}$ & $\begin{array}{c}\text { Percen } \\
\text { tage }\end{array}$ & $\begin{array}{c}\text { 't' } \\
\text { value }\end{array}$ & $\begin{array}{c}\text { Signific } \\
\text { ance }\end{array}$ \\
\hline Neonatal sepsis & 2 & 2.6 & \multirow{5}{*}{41.178} & \multirow{5}{*}{0.000} \\
\hline $\begin{array}{l}\text { Perinatal } \\
\text { Asphyxia }\end{array}$ & 4 & 5.3 & & \\
\hline Neonatal deaths & 0 & 0 & & \\
\hline NICU observation & 21 & 27.6 & & \\
\hline No complications & 49 & 64.5 & & \\
\hline \multicolumn{5}{|c|}{ Table 12: Neonatal Morbidity and Mortality } \\
\hline
\end{tabular}




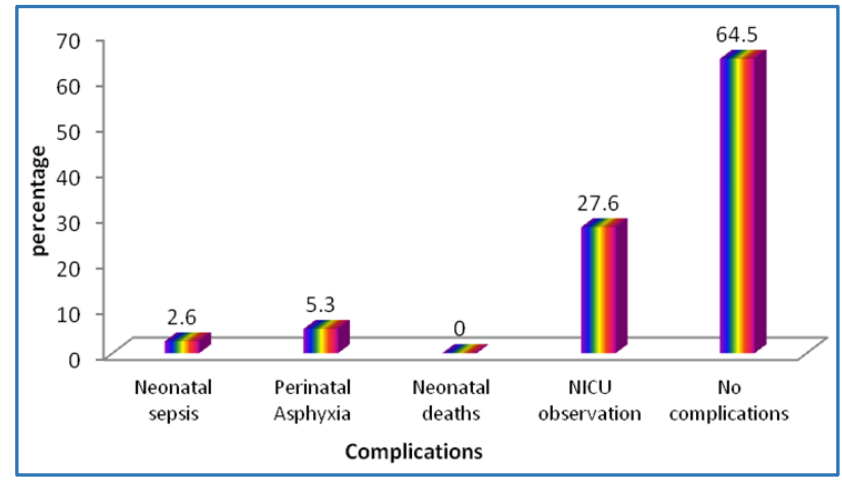

Fig. 12: Neonatal Morbidity and Mortality

\begin{tabular}{|c|c|c|c|c|c|}
\hline \multirow{4}{*}{$\begin{array}{c}\text { No of } \\
\text { Patients }\end{array}$} & \multicolumn{3}{|c|}{$\begin{array}{c}\text { Duration of PROM } \\
\text { (Latency) }\end{array}$} & $\begin{array}{c}\text { Chi } \\
\text { squ }\end{array}$ & $\begin{array}{c}\text { Signif } \\
\text { icanc } \\
\text { e }\end{array}$ \\
\cline { 2 - 4 } & $\begin{array}{c}<12 \\
\text { hrs. }\end{array}$ & $\begin{array}{c}12-24 \\
\text { hrs. }\end{array}$ & $\begin{array}{c}>24 \\
\text { hrs. }\end{array}$ & $\begin{array}{c}\text { are } \\
\text { val } \\
\text { ue }\end{array}$ & \\
\cline { 2 - 4 } & $\begin{array}{c}60 \\
(80 \%)\end{array}$ & $\begin{array}{c}11 \\
(14.7 \%)\end{array}$ & $\begin{array}{c}4 \\
(5.3 \%)\end{array}$ & \\
\hline $\begin{array}{c}\text { Puerperal } \\
\text { pyrexia }\end{array}$ & $\begin{array}{c}2 \\
(3.3 \%)\end{array}$ & $\begin{array}{c}5 \\
(45.5 \%)\end{array}$ & $\begin{array}{c}1 \\
(25 \%)\end{array}$ & & \\
\hline $\begin{array}{c}\text { Chorioamni } \\
\text { onitis }\end{array}$ & 0 & $\begin{array}{c}1 \\
(9.1 \%)\end{array}$ & 0 & \multirow{2}{*}{0.1} & \multirow{2}{*}{0.130} \\
\hline $\begin{array}{c}\text { Neonatal } \\
\text { sepsis }\end{array}$ & 0 & 0 & $\begin{array}{c}2 \\
(50 \%)\end{array}$ & & \\
\hline & & 0 & & \\
\hline
\end{tabular}

Table 13: Relation of Duration of Rupture of Membranes with Maternal and Neonatal Infectious Complications

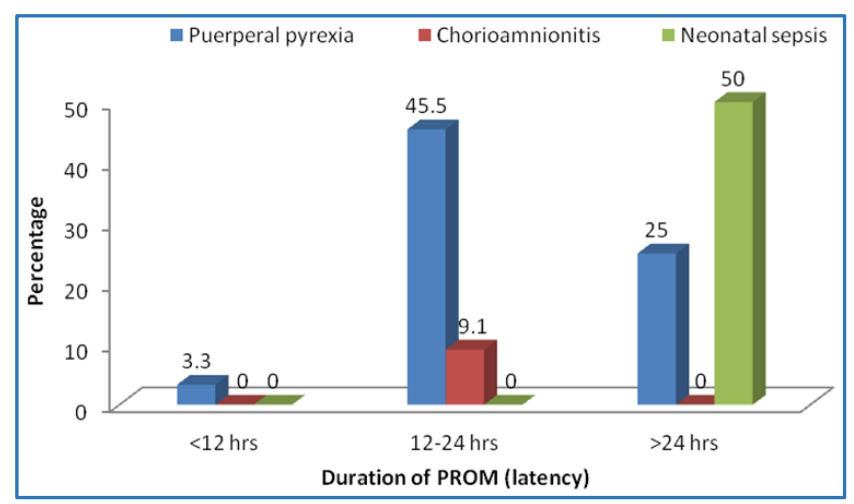

Fig. 13: Relation of Duration of Rupture of Membranes with Maternal and Neonatal Infectious Complications

\section{CONCLUSION}

PROM at term occurs more frequently in nulliparous women of low socioeconomic class. Genitourinary infection in current pregnancy, history of abortions, recent coitus, previous history of PROM, malpresentations, and multiple gestation were identified as other risk factors.

Incidence of LSCS and instrumental delivery were higher with non-reassuring foetal heart rate as the most common indication for LSCS. There were significant maternal and neonatal morbidity, but no mortality. Infections have increased with increasing period of latency.

Thus to conclude, overall incidence of maternal and neonatal infectious complications were very less in our study that could be explained by good antenatal care, good intrapartum management, sterile speculum examination, minimal digital cervical examination, antibiotic prophylaxis, and last but not the least, early induction of patients in our study by reducing the duration of latency had contributed for the reduction in the incidence of infectious complications and maternal and perinatal morbidity.

However, further extensive comparative studies are needed to validate our conclusion.

\section{REFERENCES}

1. Amjad N, Rasheed F, Imran T. Comparison of the response of oxytocin versus prostaglandin E2 vaginal pessary for labour induction in pre-labour rupture of membranes. Annals 2009;15(2):80-4.

2. Dare MR, Middleton P, Crowther CA, et al. Planned early birth versus expectant management (waiting) for prelabour rupture of membranes at term (37 weeks or more). Cochrane Database Syst Rev 2006:CD005302.

3. Gibbs RS, Blanco JD, St Clair PJ, et al. Quantitative bacteriology of amniotic fluid from women with clinical intra-amniotic infection at term. J Infect Dis 1982;145(1):1-8.

4. American college of obstetricians and gynaecologists, premature rupture of membranes. ACOG Practice Bulletin No. 1, Washington, DC: ACOG 1998.

5. Alger LS, Lovchik JC, Hebel JR, et al. The association of chlamydia trachomatis, Neisseria gonorrhoeae, and group $b$ streptococci with preterm rupture of the membranes and pregnancy outcome. Am J Obstet Gynaecol 1988;159(2):397-404.

6. Amstey MS, Steadman KT. Asymptomatic gonorrhea and pregnancy. J Am Vener Dis Assoc 1976;3(1):14-6.

7. Linn S, Schoenbaum SC, Monson RR, et al. The relationship between induced abortion and outcome of subsequent pregnancies. Am J Obstet Gynaecol 1983;146(2):136-40.

8. Ekwo EE, Gosselink CA, Woolson R, et al. Risks for premature rupture of amniotic membranes. Int J Epidemiol 1993;22(3):495-503.

9. Bou-Resli MN, Al-Zaid NS, Ibrahim ME. Full-term and prematurely ruptured foetal membranes. An ultrastructural study. Cell Tissue Res 1981;220(2): 263-78.

10. Skinner SJ, Campos GA, Liggins GC. Collagen content of human amniotic membranes: effect of gestation length and premature rupture. Obstet Gynaecol 1981;57(4):487-9.

11. Polzin WJ, Brady K. Mechanical factors in the aetiology of premature rupture of the membranes. Clin Obstet Gynaecol 1991;34(4):702-14.

12. Seaward PG, Hannah ME, Farine D, et al. Evaluation of predictors of neonatal infection in infants born to patients with premature rupture of membranes at term. Am J Obstet Gynaecol 1998;179(3 Pt 1):635-9.

13. Ratanahorn W, Srijariya W, Chamnanvana HS, et al. Incidence of neonatal infection in newborn infants with a maternal history of premature rupture of membranes (PROM) for 18 hours or longer. Clinical practice guideline. J Med Assoc Thai 2005;88(7):973-8.

14. Hannah ME, Ohlsson A, Farine D, et al. Induction of labour compared with expectant management for prelabour rupture of the membranes at term. N Engl J Med 1996;334:1005-10.

15. Challak M, Bottoms SF. Induction of labour in patients with term PROM: effect on perinatal outcome. Foetal daughter 1999;14(3):138-42. 
16. Vaishnav J, Vaishnav G. A study of feto-maternal outcome in patients with pre-labour rupture of membranes at term ( $>37$ weeks). Medicine Science 2012;1(2):118-24.

17. Tavassoli F, Ghasemi M, Mohamadzade A, et al. Survey of pregnancy outcome in preterm premature rupture of membranes with amniotic fluid index $<5$ and $\geq 5$. Oman Medical Journal 2010;25(2):118-23.

18. Hassan B, Maamouri G, Mafinejad S. Neonatal complication of PROM. Maced J Med Sci 2011;4(1):93-8.

19. Ladfors L, Mattsson LA, Eriksson M, et al. A randomised trial of two expectant managements of pre-labour rupture of the membranes at 34 to 42 weeks. Br J Obstet Gynaecol 1996;103(8):755-62.

20. Spinillo A, Nicola S, Piazzi G, et al. Epidemiological correlates of preterm premature rupture of membranes. Int J Gynaecol Obstet 1994;47(1):7-15.

21. Noor S, Fawwad A, Shahzad H, et al. Foetomaternal outcome in patients with or without premature rupture of membranes. J Ayub Med Coll Abbottabad 2010;22(1):164-7.

22. Romero R, Chaiworapongsa T, Espinoza J. Micronutrients and intrauterine infection, preterm birth and the foetal inflammatory response syndrome. J Nutr 2003;133(5Suppl 2):1668S-73.

23. Harger JH, Hsing AW, Tuomala RE, et al. Risk factors for preterm premature rupture of foetal membranes: a multicenter case-control study. Am J Obstet Gynaecol 1990;163(1 Pt 1):130-7.

24. Naeye RL, Peters EC. Causes and consequences of premature rupture of foetal membranes. Lancet 1980;1(8161):192-4.

25. Mills JL, Harlap S, Harley EE. Should coitus late in pregnancy be discouraged? Lancet 1981;318(8238): 136-8.

26. Erdemoglu E, Mungan T. Significance of detecting insulinlike growth factor binding protein-1 in cervicovaginal secretions: comparison with Nitrazine test and amniotic fluid volume assessment. Acta Obstet Gynaecol Scand 2004;83(7):622-6.
27. Grant JM, Serle E, Mahmood T, et al. Management of prelabour rupture of the membranes in term primigravidae: report of a randomised prospective trial. Br J Obstet Gynaecol 1992;99(7):557-62.

28. Rhydstrom H, Kumaran AS, Ingemarsson I. PROM at term: obstetric outcome with oxytocin stimulation in relation to parity and cervical dilatation at admission. Acta Obstetricia act Gynaecological Scan 1986;65(6):587-91.

29. Imseis HM, Trout WC, Gabbe SG. The microbiologic effect of digital cervical examination. Am J Obstet Gynaecol 1999;180(3 Pt 1):578-80.

30. Chaim W, Bashiri A, Bar-David J, et al. Prevalence and clinical significance of postpartum endometritis and wound infection. Infect Dis Obstet Gynaecol 2000;8(2):77-82.

31. Andrews WW, Hauth JC, Cliver SP, et al. Randomised clinical trial of extended spectrum antibiotic prophylaxis with coverage for Ureaplasma urealyticumto reduce post-caesarean delivery endometritis. Obstet Gynaecol 2003;101:1183.

32. Ottervanger HP, Keirse MJ, Smit W, et al. Controlled comparison of induction versus expectant care for prelabour rupture of the membranes at term. J Perinat Med 1996;24(3):237-42.

33. Ladfors L, Tessin I, Mattsson LA, et al. Risk factors for neonatal sepsis in offspring of women with pre-labour rupture of the membranes at 34-42 weeks. Journal of Perinatal Medicine 1998;26(2):94-101.

34. Yancey MK, Duff P, Kubilis P, et al. Risk factors for neonatal sepsis. Obstet Gynaecol 1996;87(2):188-94.

35. Wagner MV, Chin VP, Peters CJ, et al. A comparison of early and delayed induction of labour with spontaneous rupture of membranes at term. Obstet Gynaecol 1989;74(1):93-7. 